treason. To date, the Prosecutor's Office is considering an alternative to defining an armed conflict in eastern Ukraine. It is a question of the possibility of applying the provisions of the Rome Statute concerning both international and non-international armed conflict. The situation on the territory of the Crimea is qualified as an international armed conflict between Ukraine and Russia, which arose no later than on 26 February 2014 and continues the occupation of the peninsula.

Also, the defendants for high treason cite their lack of Ukrainian citizenship in the transition to Russia during the armed conflict in February 2014. As the main argument is the Decree of the President of Ukraine "On withdrawal from the citizenship of Ukraine", signed by V. F. Yanukovych. Such documents are not recognized by the bodies of state power of Ukraine as official, which leads to recognition by the court of such persons as subjects of high treason.

The most controversial problems could be solved by the International Criminal Court, which would establish the existence or absence of armed conflicts in the territory of Ukraine, their nature, parties, period of existence and other legal consequences. At the same time, participants in criminal proceedings, choosing and applying the provisions of Ukraine on criminal responsibility on high treason, should take into account the existing conclusions of the Court of Cassation, as set out in the decisions of the Supreme Court.

Keywords: state treason, armed conflict, International Criminal Court.

DOI: $10.33766 / 2524-0323.89 .89-101$

УДК 342.7

О. А. Любчик,

доктор юридичних наук, доцент, професор кафедри державно-правових дисциплін Луганського державного університету внутрішніх справ імені Е. О. Дідоренка

(м. Сєвєродонецьк, Україна)

e-mail: lyubchikaa@gmail.com

iDhttps:/ / orcid.org/0000-0002-8239-2129

\title{
«ГРА СЛІВ» 3 ТЯЖКИМИ НАСЛІДКАМИ, АБО ЩО ТАКЕ МЕДИЧНА ДОПОМОГА
}

У статті досліджуються сутність, ознаки та визначення поняття «медична допомога» як юридично значущого терміна, співвідношення цього поняття 3 поняттям «медична послуга». Досліджуються правові позищією законодавця і Конституційного Суду України з цього приводу та ставлення до цього питання науковців. Проведений порівняльний аналіз правової природи термінів «медична допомога» та «медична послуга». Визначається стан і тенденщії правового регулювання захисту прав людини на здоров'я та життя в Україні. Запропоновані напрямки вдосконалення правового регулювання щодо захисту прав людини на здоров'я та життя.

Ключові слова: медична допомога, медична послуга, захист прав людини на здоров'я та життя, тенденції правового регулювання, законодавче забезпечення захисту прав людини.

() Любчик О. А., 2020 
Постановка проблеми. Останніми роками в Україні, яка декларує прагнення до європейських цінностей та проголошує прихильність до європейських соціальних стандартів, помітно погіршився стан справ із дотриманням прав людини у сфері охорони здоров'я, захисту їі прав на гідний рівень життя та захисту права кожного на саме життя та здоров' я. Суттєвий вплив на таку реальність надає низький рівень економічного розвитку суспільства та, як наслідок цього, низький рівень життя громадян України; різновекторні політичні процеси; військові дії, у яких бере участь Україна; недостатність здійснюваних заходів щодо подолання корупщії та ін. Але ж є і такі фактори, які не залежать від зовнішнього впливу на діяльність держави, не пов'язані з діяльністю тіньових структур та процесів, і мінімізацію цих факторів забезпечило би просте виконання Конституції України, діючих законів та рішень Конституційного Суду України. Саме таким фактором, такою штучною проблемою стала проста підміна термінів, які закріплені в Конституції України, Основах законодавства України про охорону здоров'я та інших нормативних актах. Мова йде про словосполучення «медична допомога» та «медичні послуги». Пересічна людина, навіть фахівець із вищою юридичною освітою, який цілеспрямовано не досліджував сутність цих термінів, не одразу зрозуміє їх корінні відмінності, а зрозуміти, що саме ці відмінності порушують право всіх громадян України на здоров'я та безпосередньо життя зовсім здається абсурдом. Проте саме такий механізм (підміни понять) закладений у діючих нормативних актах, які сьогодні регулюють порядок, умови, підстави, обсяг та платність (або безоплатність) здійснення медичних заходів, з боку державних та комунальних медичних закладів, для забезпечення реалізації права кожної людини й громадянина України на життя та здоров'я.

Аналіз останніх досліджень і публікацій. Проблеми реалізації права на життя та здоров'я в Україні вивчали такі фахівці в галузі права, як: С. В. Антонов, С. Б. Булеца, О. М. Берназ-Лукавецька, В. С. Віткова, В. Д. Волков, В. О. Галай, В. Г. Гінзбург, 3. А. Дікінова, Л. М. Дешко, О. А. Сникєєв, В. П. Заблоцький, З. В. Каменєв, А. Б. Литовка, Г. А. Миронова, О. О. Прасов, І. Я. Смотров, А. В. Тихомиров, І. В. Тимофєєв, М. К. Хобзей та ін. Проте проблема наукового визначення понять «медична допомога» та «медична послуга» до сьогодні не є розв'язаною, і донині існують також суперечності діючого законодавства щодо застосування цих термінів.

Формулювання цілей. Метою цього дослідження є визначення дефініції «медична допомога» як юридично значущого терміна та його співвідношення 3 поняттям «медична послуга», з'ясування правової природи цих понять; на підставі зроблених висновків - визначення стану і тенденщій правового регулювання захисту прав людини на здоров'я та життя в Україні.

Виклад основного матеріалу. Національне відродження та державне будівництво в Україні потребує корінних змін в усіх сферах суспільного життя, відродження процесів дотримання соціальних прав громадян, забезпечення реальних гарантій їх реалізації. Стаття 21 Конституції України закріплює правило, згідно з яким права і свободи людини є невідчужуваними та непорушними; стаття 22 визначає, що конституційні права і свободи гарантуються і не можуть бути скасовані та визнає, що зміст й обсяг прав і свобод при прийнятті нових законів або внесенні змін до чинних законів не може бути звужений. Такі слушні формулювання, виникають оптимістичні очікування щодо їх виконання державою. Однак не все, що проголошується, реалізується в житті. 
Оптимізм громадян мав би підвищити зміст статті 49 Конституції України, яка закріплює право кожної людини на охорону здоров'я, медичну допомогу та медичне страхування. Держава повинна створювати умови для ефективного й доступного для всіх громадян медичного обслуговування. У державних і комунальних закладах охорони здоров'я медична допомога надається безоплатно [1]. Проте реальність, 3 якою стикаються громадяни України, яскраво свідчить про те, що такі конституційні положення відбивають, скоріше, прагнення та орієнтири на майбутнє держави й суспільства, ніж реальну дійсність.

Останніми роками в Украӥні приймаються нормативні акти, які порушують норми Конституції України, обмежують права громадян на безоплатну медичну допомогу в державних і комунальних закладах охорони здоров'я, скорочують навіть самі такі заклади, створюють умови для обмеження доступу громадян на медичну допомогу. Саме тому в умовах політичної, економічної, соціальної та епідеміологічної кризи в української державі вкрай необхідно запровадити дієві механізми та створити умови для забезпечення найважливішого права людини - права на безоплатну медичну допомогу як складову права на життя та здоров'я.

3 моменту прийняття Конституції України українська влада та громадяни України дуже пишалися їі змістом; останні сподівалися, що їі положення почнуть запроваджуватись у життя. Люди ще пам'ятали високі соціальні стандарти життя та прагнули отримати гарантії їх дотримання державою, тому закріплене в статті 49 Конституції України словосполучення «право на безоплатну медичну допомогу» не давало можливостей і приводів владі посягати на таке право.

Положення цієї статті Конституції відповідали нормам міжнародного права, а саме міжнародним договорам, які ратифікувала Верховна Рада України. Так Загальна декларація прав людини від 10.12.1948 року у статті 25 закріплює, що кожна людина має право на такий життєвий рівень, зокрема їжу, одяг, житло, медичний догляд та необхідне соціальне обслуговування, який $є$ необхідним для підтримання здоров'я і добробуту їі самої та їі сім'ї, і право на забезпечення в разі безробіття, хвороби, інвалідності, удівства, старості чи іншого випадку втрати засобів до існування через незалежні від неї обставини [2]. У статті 13 Європейської соціальної хартії (ETS N35) від 1961 року йдеться, що з метою забезпечення ефективного здійснення права на соціальну та медичну допомогу, договірні сторони зобов'язуються забезпечити таке: щоб будь-якій малозабезпеченій особі, яка неспроможна отримати достатніх коштів або завдяки своїм власним зусиллям, або з інших джерел, зокрема за рахунок допомоги по соціальному забезпеченню, надавалась належна допомога, а у випадку захворювання - забезпечувався догляд, якого Вимагає стан ї̈ здоров'я [3]. Ключові посили в цих договорах свідчать про те, що держава повинна забезпечити право кожного (не тільки громадян), незалежно від майнового стану на державну допомогу, у тому числі в разі погіршення здоров'я, і медичну допомогу, яку Вимагає стан здоров'я. Тобто, погоджуючись із цими положеннями, держава бере на себе зобов' язання перед міжнародним співтовариством, а приймаючи Конституцію Украӥну - перед українським народом за надання безоплатної медичної допомоги кожному, хто ї̈ потребує, хоча б 6 державних та комунальних закладах охорони здоров'я. Треба пам'ятати, що визначення «безкоштовна медична допомога» - словосполучення умовне, усі розуміють, що кожен громадянин уже сплатив податками, зборами та іншими неподатковими платежами це своє право, і коли приходить чергова влада, вона приймає «правила гри», 
які прописані в Основному Законі держави та діючих міжнародних договорах. Якщо такі правила владу не задовольняють, то вона повинна або ініціювати зміни до Основного Закону і, згідно з цим, нести політичну відповідальність за таке рішення, або чітко дотримуватись його положень.

Однак в Україні був вибраний інший шлях: не змінюючи положення статті 49 Конституції України, підмінити поняття «медична допомога» поняттям «медична послуга» і на рівні підзаконного акту запровадити платну медицину в державних та комунальних закладах охорони здоров'я. Тобто Кабінет Міністрів України прийняв Постанову № 1138 від 17 вересня 1996 р. «Про затвердження переліку платних послуг, які надаються в державних закладах охорони здоров'я та вищих медичних закладах освіти» [4]. Ця т. зв. «передова ідея» не зразу привернула увагу суспільства, тому що той перелік «платних послуг» не стосувався профілактики та лікування розповсюджених і тяжких захворювань.

Якщо Постанова № 1138 на момент прийняття мала 26 позищій «Послуг щодо надання лікувально-профілактичної допомоги», то вже наступного року він складався 3 52. Така геометрична прогресія зростання кількості платних послуг на фоні падіння економіки країни та низького рівня забезпечення білышості населення не залишилася поза увагою суспільства. 3 цього моменту бере свій початок як теоретична дискусія щодо «корінних відмінностей» між поняттями «медична допомога» та «медична послуга», так і поступове зменшення змістовного наповнення медичної допомоги в розумінні статті 49 Конституції України.

Через те вже в наступному 1998 року Конституційний Суд України (КСУ) рiшенням у справі (про платні медичні послуги) від 25 листопада N 1-29/98 визнав положення Постанови №1138 неконституційним [5]. У цьому рішенні було вказано наступне: «Зміст поняття «медична допомога» Конституція України не розкриває. Відсутнє його визначення також в Основах законодавства України про охорону здоров'я та інших нормативних актах. Однак у медичній науці поняттям «медична допомога» переважно охоплюються лікування, профілактичні заходи, які проводяться при захворюваннях, травмах, пологах, а також медичний огляд та деякі інші види медичних робіт. Зміст близького до «медичної допомоги» поняття «медична послуга» до цього часу залишається не визначеним не тільки в нормативних актах, зокрема в названій Постанові КМУ, а також у медичній літературі». Конституційний Суд зазначив також: «...значна частина перерахованих у цъьому Переліку платних медичних послуг підпадає під поняття «медична допомога», ненадання якої може завдати iстотної шкоди здоров' ю хворих [5, п. 2, абз. 7]. Тобто Конституційний Суд не називає дії, які перераховані в Переліку платних послуг, як послуги, а зазначає, що це є «медична допомога».

До «медичної допомоги» він відносить ряд визначених у Переліку платних послуг дій, які безпосереднъ пов' язані з лікуванням хворих та профілактикою захворюванъ. Це зокрема профілактичні медичні огляди з винесенням висновку про стан здоров'я на прохання громадян (розділ I, пункт 15); зубне, вушне, очне протезування дорослого населення (розділ I, пункт 25); надання всіх видів медичної та лікувально-профілактичної допомоги (крім першої невідкладної) особам, обслуговування яких не передбачено даним закладом (розділ I, пункт 37); надання додаткової медичної інформації на прохання громадян (довідки, виписки з історії хвороби) (розділ II, пункт 3) та інші [5, п. 2, абз. 7]. 
Тобто Конституційний Суд України в рамках повноважень наголошує наступне: 1) визначає сутність та суттєві ознаки «медичної допомоги» (п. 2, абз. 8); 2) називає дії, які знаходяться в Переліку платних послуг, - «виконнання робіт» (п. 2, абз. 8); 3) визначає дії, які знаходяться в Переліку платних послуг і які відносяться до медичної допомоги, та дії, які за певних обставин можуть розглядатися як медична допомога (п. 2, абз. 7,8$)$; 4) визначає незначну частину положень із зазначеного Переліку, яка може розглядатися як послуги, надання яких безоплатно в державних закладах охорони здоров'я не може брати на себе держава (п. 2, абз. 9) [5].

Це правова позиція КСУ, і не погоджуватись з нею, оспорювати ї̈, оскаржувати, не виконувати, не звертати уваги або пропонувати інший підхід до тлумачення статті 49 Конституції не має права жоден державний орган або юрист-фахівець, який інтерпретує діюче законодавство. Згідно зі ст. 7 Закону Украӥни «Про Конституційний суд України», єдиний орган, який може легально тлумачити Конституцію, - це Конституційний суд Украӥни. У 2016 році Конституцію Украӥни було доповнено статтею 151-2, у якій закріплено, що рішення та висновки, ухвалені Конституційним Судом України, є обов'язковими, остаточними й не можуть бути оскаржені.

3 цього Рішення КСУ можна зробити висновок, що він не сформулював чітке визначення поняття «медична допомога», але ж охарактеризував ії сутність та визначив суттєві ознаки й конкретні дії, вказані в Переліку платних послуг, які є медичною допомогою. Науковці за цими «лекалами» мають можливість позмагатись щодо чіткого та слушного визначення терміна «медична допомога».

Вказану правову позищію КСУ підтримав також у своєму Рішенні від 29 травня 2002 року N 10-рп/2002 щодо офіційного тлумачення положення ч. 3 статті 49 Конституції України: «...у державних і комунальних закладах охорони здоров'я медична допомога надається безоплатно» (справа про безоплатну медичну допомогу) [6]. Так було визначено:

- загальньний зміст безоплатної медичної допомоги. Він полягає у відсутності для всіх громадян обов'язку сплачувати за надану їм медичну допомогу в державних і комунальних закладах охорони здоров'я як у момент, такі до чи після її отримання. Словосполучення «безоплатність медичної допомоги» означає неможливість стягування з громадян плати за таку допомогу в державних і комунальних закладах охорони здоров'я у будь-яких варіантах розрахунків (готівкою або безготівкових): чи у вигляді «добровільних внесків» до різноманітних медичних фондів, чи у формі обов'язкових страхових платежів (внесків) тощо [6, п. 4, абз. 6];

- положення статті 49 Конституції не забороняють можливості надання громадянам медичних послуг, які виходять за межі медичної допомоги (за термінологією Всесвітньої організації охорони здоров'я - «медичних послуг другорядного значення», «парамедичних послуг»), у зазначених закладах за окрему плату. Перелік таких платних послуг не може вторгатися $b$ межі безоплатної медичної допомоги i, відповідно до вимог п. 6 ч.1 статті 92 Конституції, має встановлюватися законом [6, п. 4, абз. 8].

У цьому ж Рішенні було вирішено:

- положення ч. 3 статті 49 Конституції «у державних $і$ комунальних закладах охорони здоров'я медична допомога надається безоплатно» треба розуміти так, що в державних та комунальних закладах охорони здоров'я медична допомога надається всім громадянам незалежно від їі обсягу та без попереднъого, поточного або наступного їх розрахунку за надання такої допомоги; 
- поняття «медична допомога», умови запровадження медичного страхування, у тому числі державного, формування і використання добровільних медичних фондів, а також порядок надання медичних послуг, які виходять за межі медичної допомоги, на платній основі в державних і комунальних закладах охорони здоров'я та перелік таких послуг мають бути визначені законом.

Цікаво наголосити, що в розглянутому Рішенні N 10-рп/2002 КСУ визнав, що визначення понять «здоров'я», «охорона здоров'я», «заклади охорони здоров'я», «медична допомога», «медична послуга», «медичне обслуговування», «гарантований рівень медичної допомоги», «стандарти медичної допомоги», «медичне страхування», «доступність медичного обслуговування», «безоплатність медичної допомоги», «платність медичних послуг» та інших суттєвих для розгляду справи термінів надали для дослідження КСУ майже всі провідні наукові центри, медичні університети й академії, академічні інститути, відомі вчені і фахівці-практики, об'єднані у Всеукраїнське лікарське товариство, спеціалісти Свропейського регіонального бюро Всесвітньої організащії охорони здоров'я, що працюють в Україні. Дефініції зазначених понять і термінів, наведені науковцями й практиками, різноманітні і збігаються лише в окремих частинах чи елементах. Так «медична допомога» $\mathrm{i}$ «медична послуга» трактуються і як синоніми, і як антоніми, і як частина одна одної. Так само співвідносяться поняття «медична допомога» $\mathrm{i}$ «медичне обслуговування» та інші [6, п. 3].

До речі, у цьому Рішенні КСУ наводить позищії державних органів із приводу поставленого перед КСУ питанням таким чином [6, п. 2]:

- на думку Президента України, Конституція гарантує надання лище частини з комплексу медичних послуг у вигляді безоплатної медичної допомоги, що тягне за собою здійснення останньої тільки на гарантованому рівні й у визначеному законодавством обсязі;

- Комітет ВРУ 3 питань охорони здоров'я, материнства та дитинства зміст поняття безоплатності медичної допомоги тлумачить як повну фінансову забезпеченість визначених згідно з вимогами закону основних видів медичних послуг та придбання необхідних для їх надання основних медикаментів за рахунок сформованих у колективному порядку (оподаткування чи сплати, у тому числі найманими працівниками, обгрунтованих страхових внесків) контрольованих державою суспільних фінансових ресурсів.

Сутність терміна «безоплатність медичної допомоги», на думку МОЗ України, вичерпується відсутністю безпосереднъого розрахунку пацієнта за одержану послугу не лише $b$ момент, a й до та після ї̈ надання. У цьому разі витрати на медичну допомогу відшкодовуються за рахунок бюджету, страхових фондів або інших джерел, визначених законодавством.

Міністерство фінансів України вбачає розрив між проголошеними Конституцією України гарантіями щодо надання безоплатної медичної допомоги та економічними можливостями держави. Формулює безоплатність як відсутність прямого розрахунку пацієнта за медичну допомогу виключно в момент ї̈ надання.

Такі кардинально різні погляди державних органів на зміст медичної допомоги свідчить про розбіжні погляди представників влади на роль держави в житті суспільства, на ті цінності, які вони сповідують, та на рівень відповідальності перед 
громадянами України, що вони усвідомлюють. Також це свідчить про рівень правового нігілізму, який міцно закріпився в українській політищі. Такий стан справ створив умови для того, що, всупереч Конституції України та рішенням КСУ, продовжує діяти Постанова КМУ № 1138, яка зараз нараховує 39 пунктів, у багатьох з яких визначені «платні медичні послуги», які за змістом є медичною допомогою.

Наприклад: «Медична допомога, що надається в стаціонарних умовах лікарями відповідної спеціалізації (надання консультацій, проведення діагностики, лікування, реабілітації та профілактики хвороб, травм, отруєнь, патологічних станів, ведення фізіологічних станів (під час вагітності), із забезпеченням харчування та умов для перебування в палаті в закладах охорони здоров'я МВС за договорами з фізичними особами та юридичними особами незалежно від форми власності» [4, п. 38].

Тож перелік медичних заходів (дій), визначених у Постанові КМУ № 1138, протирічить не тільки вказаним рішенням КСУ але ж й існуючому легальному визначенню «медична допомога», яке надано в статті 3 Закону України «Основи законодавства України про охорону здоров'я» від 1992 року, а саме: «медична допомога це діяльність професійно підготовлених медичних працівників, спрямована на профілактику, діагностику, лікування та реабілітацію у зв'язку з хворобами, травмами, отруєннями і патологічними станами, а також у зв'язку з вагітністю та пологами» [7] . Це визначення дефініції «медична допомога» відповідає духу та букві Рішень КСУ N1-29/98 та N 10-рп/2002.

Ще одним суттєвім та нищівним кроком щодо захисту права на здоров'я та життя громадян України був прийнятий Закон України «Про державні фінансові гарантії медичного обслуговування населення» № 2168-VIII від 19 жовтня 2017 року. [8] Відповідно до статті 3 цього Закону, держава гарантує повну оплату, згідно з тарифом за рахунок коштів Державного бюджету України, надання громадянам необхідних їм медичних послуг та лікарських засобів, що передбачені програмою медичних гарантій. Формулювання «згідно 3 тарифом» не відповідає положенням ст. 3 Основ законодавства про охорону здоров'я, досліджуваним рішенням КСУ та, звісно, статті 49, а також статті 22 Конституції України, яка наголошує: «Конституційні права і свободи гарантуються і не можуть бути скасовані. При прийнятті нових законів або внесенні змін до чинних законів не допускається звуження змісту та обсягу існуючих прав і свобод».

КСУ в рішенні N 1-29/98 вважає неприйнятними пропозищії окремих державних органів щодо необхідності встановлення якихось меж безоплатної медичної допомоги у вигляді ії гарантованого рівня, надання такої допомоги лише неспроможним верствам населення чи «в рамках, визначених законом» тощо. Безоплатна медична допомога, передбачена Конституцією України і повинна надаватись усім громадянам у повному обсязі, тобто задовольняти потреби людини в збереженні або відновленні здоров'я [5, п. 4, абз. 9].

Постає питання: а що як цього «тарифу» невистачить на лікування людини!? Що робити людині? А закріплених тарифів Постановою КМУ № 65 від 5 лютого 2020 р. «Деякі питання реалізації програми державних гарантій медичного обслуговування населення у 2020 році» дійсно недостатньо, якщо порівняти ці «тарифи» та ціни на «платні медичні послуги». 
Наприклад: Постановою КМУ від 27 грудня 2019 р. № 1161 в Постанову КМУ № 1138 внесли додаткові платні послуги для трьох державних установ Національної академії медичних наук України [9]. У цих спеціалізованих установах (державних!) можуть бути надані платні медичні послуги, за зверненням громадян без відповідного направлення або за самозверненням (крім невідкладних станів).

Перелік таких послуг на ці три установи сягає аж 956 різновидів та передбачає конкретні тарифи на такі послуги, як: п. 617. - Зондування порожнин серця в дітей - 22834 грн.; п. 628. - Радикальна корекція загального артеріального стовбура в дітей - 89831 грн.; п. 637. -Ушивання дефекту міжшлуночкової перегородки в дітей - 63 007 грн.; п. 656. - Протезування клапана серця в дітей - 67938 грн.

Сьогодні і вчені, і практики одностайні в думщі, що ст.ст. 33, 35, 58, 67, 68, 77 Основ законодавства про охорону здоров'я визначають вузлові складові медичної допомоги (швидка, невідкладна, первинна, спеціалізована, високоспеціалізована тощо) [10, с. 35-36; 11]. Так само слушно зауважує В. С. Віткова про право людини на медичну допомогу: «...це не стільки право вимагати, скільки можливість отримувати медичну допомогу в необхідному обсязі і в необхідний термін» [12, с. 35].

Можна стверджувати, що на сьогодні вже перелік «платних послуг», які надаються в державних і комунальних закладах охорони здоров'я та державних установах Національної академії медичних наук України досяг свого максимуму, ні Конституція України, ні норми міжнародного права, ні рішення КСУ не змогли припинити цю тенденщію. Соціальні наслідки таких процесів правового нігілізму наочно демонструє виступ голови Комітету ВРУ з питань охорони здоров'я Ольги Богомолець на засіданні круглого столу, який відбувся 10 червня 2019 року, 3 теми: «Перемогти смерть: ключові чинники, що впливають на тривалість життя українців» [13]. У своїй доповіді вона зазначає, що Україна належить до трійки європейських держав з найвищою інтенсивністю природного скорочення населення. За інформацією Державної служби статистики, у 2018 рощі померло 587,7 тисяч осіб, відповідно, за рік за рахунок природного скорочення (тобто різниці між числом народжених і померлих) населення зменшилось на 251,8 тисяч осіб. У січні - березні 2019 року народилося 76 125, а померло - 159264 осіб, отже, природний приріст становив - мінус 83139 особи. Основною причиною смерті протягом останніх років є серцево-судинні захворювання (67,0 \%), на другому місці - новоутворення (13,6 \%). Зовнішні причини призвели до 5,4 \% смертей. Наприклад, у Франщії і Японії серцево-судинні захворювання стають причиною летальності в 29 \% випадків, а в США $-31 \%$.

Щорічно від онкологічних хвороб помирає понад 400 тисяч українців (у середньому щодня гине більше 1 тисячі осіб). Сьогодні в Україні налічується близько 1 мільйона хворих на злоякісні новоутворення, з них - близько 6 тисяч дітей. Причому показники онкозахворюваності мають стійку тенденцію до зростання, і наша держава посідає друге місце в Свропі за темпами поширення раку. Щорічно в Україні білыше 150 тисяч осіб дізнаються, що вони онкохворі. Щодня рак виявляють у 450 людей.

Такі тяжкі наслідки в тому числі звичайної «гри слів» та правового нігілізму в Україні! 
Висновок. Отже, медична допомога у визначенні статті 3 Основ законодавства Украӥни про охорону здоров'я - це діяльність професійно підготовлених медичних працівникіל, спрямована на профілактику, діагностику, лікування та реабілітацію у зв'язку з хворобами, травмами, отруєннями і патологічними станами, а також у зв'язку з вагітністю та пологами.

Надається медична допомога як у державних та комунальних, так і в приватних закладах охорони здоров'я та фізичними особами - підприємцями, які зареєстровані й одержали відповідну ліцензію та мають відповідну освіту. Треба наголосити, що не заклади надають «медичну допомогу», а їх працівники, або фізичні особи-підприемці, якщо вони мають відповідну ліцензію, відповідну (медичну) освіту та особисто надають таку допомогу пацієнту.

У державних та комунальних закладах охорони здоров'я медична допомога надається безоплатно; фактичною підставою для ії надання є звернення громадян за такою допомогою, юридичною підставою є стаття 49 Конституції України та досліджені Рішення Конституційного Суду України № 1-29/98 та № 10-рп/2002.

У приватних закладах медична допомога надається в рамках юридичної конструкції «медична послуга». Зміст цього терміна пропонує стаття 3 Основ законодавства про охорону здоров'я, а саме: «послуга з медичного обслуговування населення (медична послуга) - послуга, що надається пацієнту закладом охорони здоров'я або фізичною особою-підприємцем, яка зареєстрована та одержала в установленому законом порядку ліцензію на провадження господарської діяльності 3 медичної практики, та оплачується ï̈ замовником. Як бачимо, навіть ця стаття не визначає дефініції медичної послуги, використано формулу «послуга - це послуга».

Звертаючи увагу на особливе значення здоров'я та життя людини як об'єктів захисту та спираючись на проведене дослідження, на нашу думку, медична послуга ие дії (медичні заходи), які надаються на підставі укладеного оплатного договору між паиієнтом та приватним закладом охорони здоров'я з метою профілактики, діагностики, лікування та реабілітаиії замовника послуги або дї̈ державного та комунального закладу охорони здоров'я, спрямовані на забезпечення потреб пацієнта, які не стосуються його профілактики, діагностики, лікування ӥ реабілітації (медичної допомоги), але тісно пов'язані з ними та сприяють медичній допомозі, та надаються на підставі оплатного договору між пацієнтом і таким закладом.

\section{Використані джерела:}

1. Конституція України: прийнята на п'ятій сесії Верховної Ради України 28 червня 1996 року. Відомості Верховної Ради України. 1996. № 30. Ст. 141

2. Загальна декларація прав людини від 10.12.1948 року. - [Електрон. ресурс]. URL: https://zakon.rada.gov.ua/laws/show/995_015

3. Свропейська соціальна хартія (ETS N 35) від 18.10.1961 року. - [Електрон. pecypc]. URL: https://zakon.rada.gov.ua/laws/show/994_300

4. Про затвердження переліку платних послуг, які надаються в державних закладах охорони здоров'я та вищих медичних закладах освіти. Постанова КМУ від 17 вересня 1996 p. N 1138. - [Електрон. ресурc]. URL: https:// zakon.rada. gov.ua/ laws/ show/1138-96-\%D0\%BF/ed19960917 
5. Рішення Конституційного Суду України у справі за конституційним поданням 66 народних депутатів України щодо відповідності Конституції України (конституційності) Постанови Кабінету Міністрів України «Про затвердження переліку платних послуг, які надаються в державних закладах охорони здоров'я та вищих медичних закладах освіти» (справа про платні медичні послуги) від 25 листопада 1998 року N 15-рп/98. - [Електрон. ресурс]. URL: https:/ / zakon.rada. gov.ua/ laws/ show/ v015p710-98

6. Рішення Конституційного Суду України у справі за конституційним поданням 53 народних депутатів України щодо офіційного тлумачення положення частини третьої статті 49 Конституції України «у державних і комунальних закладах охорони здоров'я медична допомога надається безоплатно» (справа про безоплатну медичну допомогу) від 29 травня 2002 року N 10-рп/2002 - [Електрон. ресурс]. URL: https://zakon.rada. gov.ua/laws/show/v010p710-02

7. Закон України «Основи законодавства України про охорону здоров'я» від 19.11.1992 року № 2801-ХІІ // Відомості Верховної Ради України (ВВР), 1993, № 4, ст. 19. - [Електрон. pecypc]. URL: https://zakon.rada. gov.ua/laws/show/2801-12/ed20150101 /find?text=\%CC\%E5\%E4\%E8\%F7\%ED \% E0+\%E4\%EE\%EF\%EE\%EC\%EE\%E3\%E0

8. Про державні фінансові гарантії медичного обслуговування населення: Закон України від 19 жовтня 2017 року, № 2168-VIII // Відомості Верховної Ради (ВВР), 2018, № 5, ст. 31. - [Електрон. ресурс]. URL: https://zakon.rada. gov.ua/ laws/ show/ 2168-19

9. Про внесення змін до деяких постанов Кабінету Міністрів України з питань реалізащії пілотного проекту щодо зміни механізму фінансового забезпечення надання медичної допомоги. Постанова КМУ від 27 грудня 2019 р. № 1161. - [Електрон. pecypc]. URL: https:/ zakon.rada.gov.ua /laws/show/1161-2019-\%D0\%BF

10. Антонов С. В. Цивільно-правова відповідальність за заподіяння шкоди здоров'ю при наданні платних медичних послуг : Дис. канд. юр. наук:12.00.03 / Антонов С. В. Київ, 2006. 206 с.

11. Дешко Л. Проблеми цивільно-правового регулювання угод, пов'язаних 3 наданням платних медичних послуг / Л. Дешко, В. Волков. / / Правничий часопис Донецького університету. 2004. № 1. С. 42-48.

12. Віткова В. С. Конституційне право на медичну допомогу та його юридичне забезпечення в Україні: дис. на здобуття наук. ступеня канд. юр. наук: спец. 12.00.04 «конституційне право; муніципальне право» / Віткова В. С. Ужгород, 2017. 208 с.

13. «Перемогти смерть: ключові чинники, що впливають на тривалість життя українщів». Виступ голови Комітету з питань охорони здоров'я Ольгою Богомолець на засідання круглого столу який відбувся 10 червня 2019 року у Верховній Раді України. - [Електрон. ресурс]. URL: https: / / rada.gov.ua/print/172805.html

\section{References:}

1. Konstytutsiia Ukrainy: pryiniata na p'iatii sesii Verkhovnoi Rady Ukrainy 28 chervnia 1996 roku. Vidomosti Verkhovnoi Rady Ukrainy-Information of the Verkhovna Rada of Ukraine, 30, art. 141. [in Ukrainian].

2. Zahalna deklaratsiia prav liudyny vid 10.12.1948 roku. - [Elektron. resurs]. URL: https://zakon.rada.gov.ua/laws/show/995_015. [in Ukrainian]. 
3.Yevropeiska sotsialna khartiia (ETS N 35) vid 18.10.1961 roku. - [Elektron. resurs]. URL: https://zakon.rada.gov.ua/laws/show/ 994_300. [in Ukrainian].

4. Pro zatverdzhennia pereliku platnykh posluh, yaki nadaiutsia $\mathrm{v}$ derzhavnykh zakladakh okhorony zdorovia ta vyshchykh medychnykh zakladakh osvity. Postanova KMU vid 17 veresnia 1996r. N1138. - [Elektron. resurs]. URL: https:/ / zakon. rada. gov.ua/ laws/show/1138-96-\%D0\%BF/ed19960917. [in Ukrainian].

5. Rishennia Konstytutsiinoho Sudu Ukrainy u spravi za konstytutsinym podanniam 66 narodnykh deputativ Ukrainy shchodo vidpovidnosti Konstytutsii Ukrainy (konstytutsiinosti) Postanovy Kabinetu Ministriv Ukrainy "Pro zatverdzhennia pereliku platnykh posluh, yaki nadaiutsia $\mathrm{v}$ derzhavnykh zakladakh okhorony zdorovia ta vyshchykh medychnykh zakladakh osvity" (sprava pro platni medychni posluhy) vid 25 lystopada 1998 roku N 15-rp/98. - [Elektron. resurs]. URL: https:// zakon.rada. gov.ua/l aws/ show/ v015p710-98. [in Ukrainian].

6. Rishennia Konstytutsiinoho Sudu Ukrainy u spravi za konstytutsiinym podanniam 53 narodnykh deputativ Ukrainy shchodo ofitsiinoho tlumachennia polozhennia chastyny tretoi statti 49 Konstytutsii Ukrainy "u derzhavnykh i komunalnykh zakladakh okhorony zdorovia medychna dopomoha nadaietsia bezoplatno" (sprava pro bezoplatnu medychnu dopomohu) vid 29 travnia 2002 roku N 10-rp/2002 - [Elektron. resurs]. URL: https:// zakon.rada. gov.ua/laws/show/v010p710-02. [in Ukrainian].

7. Zakon Ukrainy «Osnovy zakonodavstva Ukrainy pro okhoronu zdorovia» vid 19.11.1992 roku № 2801-XII. (1993) Vidomosti Verkhoonoi Rady Ukrainy (VVR) - Verkhoona Rada of Ukraine (BBR), 4, art. 19. - [Elektron. resurs]. URL: https:// zakon. rada. gov.ua/ laws/show/2801-12/ed20150101/find?text=\%CC\%E5\%E4\%E8\%F7\%ED \%E0+\%E4\%EE \%EF\%EE\%EC\%EE\%E3\%E0. [in Ukrainian].

8. Pro derzhavni finansovi harantii medychnoho obsluhovuvannia naselennia: Zakon Ukrainy vid 19 zhovtnia 2017 roku, № 2168-VIII. (2018) Vidomosti Verkhounoi Rady (VVR) Verkhovna Rada of Ukraine (BBR), 5, art. 31. - [Elektron. resurs]. URL: https:/ /zakon.rada. gov.ua/laws/show/2168-19. [in Ukrainian].

9. Pro vnesennia zmin do deiakykh postanov Kabinetu Ministriv Ukrainy z pytan realizatsii pilotnoho proektu shchodo zminy mekhanizmu finansovoho zabezpechennia nadannia medychnoi dopomohy. Postanova KMU vid 27 hrudnia 2019 r. № 1161. - [Elektron. resurs]. URL: https://zakon.rada.gov.ua /laws/show/1161-2019-\%D0\%BF. [in Ukrainian].

10. Antonov, S. V. (2006) Tsyvilno-pravova vidpovidalnist za zapodiiannia shkody zdorov'iu pry nadanni platnykh medychnykh posluh. Candidate's thesis. S. V. Antonov, Kyiv. [in Ukrainian].

11. Deshko, L. (2004) Problemy tsyvilno-pravovoho rehuliuvannia uhod, pov'iazanykh z nadanniam platnykh medychnykh posluh. L. Deshko, V. Volkov. Pravnychyi chasopys Donetskoho universytetu- Law Journal of Donetsk University, 1, 42-48. [in Ukrainian].

12. Vitkova, V.S. Konstytutsiine pravo na medychnu dopomohu ta yoho yurydychne zabezpechennia v Ukraini. Candidate's thesis. V.S. Vitkova- Uzhhorod. [in Ukrainian].

13. «Peremohty smert: kliuchovi chynnyky, shcho vplyvaiut na tryvalist zhyttia ukraintsiv». Vystup holovy Komitetu z pytan okhorony zdorov'ia Olhoiu Bohomolets na zasidannia kruhloho stolu yakyi vidbuvsia 10 chervnia 2019 roku u Verkhovnii Radi Ukrainy. - [Elektron. resurs]. URL: https: //rada.gov.ua/print/172805.html. [in Ukrainian]. 
Любчик А. А,

доктор юридических наук, доцент, профессор кафедры государственно-правовых дисциплин Луганского государственного университета

внутренних дел имени Э. А. Дидоренко (г. Северодонецк, Украина)

\section{«ИГРА СЛОВ» С ТЯЖКИМИ ПОСЛЕДСТВИЯМИ, ИЛИ ЧТО ТАКОЕ МЕДИЦИНСКАЯ ПОМОЩЬ}

В статье исследуются сущность, признаки и определение медицинской помощи как юридически значимого термина, соотношение этого понятия с медицинской услугой. Рассмотрены правовые позиции законодателя и Конституционного Суда Украины по этому поводу, а также научный взгляд на этот вопрос. Проведён сравнительный анализ правовой природы терминов «медицинская помошь» и «медицинская услуга». Анализируются состояние и тенденции правового регулирования защиты прав человека на здоровье и жизнь в Украине. Предложены направления совершенствования правового регулирования защиты прав человека на здоровье и жизнь.

Ключевые слова: медицинская помощь, медицинская услуга, защита прав человека на здоровье и жизнь, тенденции правового регулирования, законодательное обеспечение защиты прав человека.

Lyubchik O.,

Doctor of Laws, Docent, Professor of the Department State and Legal disciplines Lugansk State University of Internal Affairs named after E. O. Didorenko

(Sievierodonetsk, Ukraine)

\section{GAME WORK WITH HARD CONSEQUENCES, OR WHAT IS MEDICAL ASSISTANCE}

This article examines the nature, characteristics and definition of medical care as the legally relevant period, the ratio of this concept with the concept of medical services. Examines the legal position of the legislator and the constitutional Court of Ukraine on this issue and the attitudes of scientists. A comparative analysis of the legal nature of the terms "medical care" and "medical services". Determined the status and trends of legal regulation of protection of human rights to health and life in Ukraine. The directions of improvement of legal regulation in relation to the protection of human rights to health and life.

In recent years in Ukraine, which declares the aspiration to European values, and proclaims its commitment to European social standards deteriorated markedly, the situation of human rights in the sphere of healthcare, protection of their rights to a decent standard of living and protection of the right of everyone to life and health.

One of the factors for this is an artificial problem which consists in the substitution of terms which enshrined in the Constitution of Ukraine, Fundamentals of legislation of Ukraine about 
health care and other regulations. We are talking about the phrase "medical assistance" and "medical services".

Determined that the state and municipal institutions health care should be provided free of charge, the factual basis for it is seeking such assistance, the legal basis is article 49 of the Constitution of Ukraine and examined the decisions of the constitutional Court of Ukraine No. 1$29 / 98$ and No. 10-RP/2002. On these grounds, the state arises, the constitutional obligation to provide free medical care in public and private healthcare institutions.

Private institutions medical care is provided under the legal construction of "medical service", which is also in article 3 of the fundamentals of legislation on health care, namely: "the service of health care (medical service) - a service that is provided to a patient by a healthcare institution or a natural person - entrepreneur, which is registered and obtained in accordance with the law the license for implementation of economic activity on medical practice, and it is paid by the customer. Customer service in health care can be the state, relevant local authorities, legal entities and individuals, including the patient." Medical service is provided in the framework of civil or economic relations, on the basis of the agreement for the implementation of paid medical services.

Keywords: medical care, medical service, protection of human rights for health and life, trends in legal regulation, legislative support for human rights protection.

DOI: 10.33766/2524-0323.89.101-109

УДК 343.9:658:343.352

I. О. Христич, кандидат економічних наук, доцент, старший науковий співробітник

Науково-дослідного інституту вивчення проблем злочинності імені академіка

В. В. Сташиса НАПрН України (м. Харків, Україна) e-mail: krystych.inna@gmail.com (iDhttps://orcid.org/0000-0001-7494-7289

\section{ПРОБЛЕМИ РОЗРОБКИ МЕТОДИКИ ВСТАНОВЛЕННЯ РЕАЛЬНИХ ОБСЯГІВ КОРУПЦІЇ В ПРИВАТНІЙ СФЕРІ УКРАЇНИ}

У статті розглянуті проблеми, які виникають при розробці методики встановлення реальних обсягів корупщії в приватній сфері. Зазначено, що можна по-різному класифікувати методи, які використовуються в кримінології для отримання та опрацювання наукової інформації. На жаль, при дослідженні рівня корупшії можна застосовувати найчастіше лише такий соціологічний метод, як опитування. Зроблено висновок, що корупщія в нашій країні стала повсякденною практикою, тому розробка методики встановлення реальних обсягів корупіії в приватній сфері є одним з найважливіших інструментів дотримання вимог антикорупщійних законів України юридичними особами приватного права.

Ключові слова: корупція, приватна сфера, соціологічні методи, масові опитування, методика, перепис населення.

() Христич I. О., 2020 